\title{
A Cultural Anthropology of Head Porterage: Fresh Insights into Unique Markets
}

\section{es Olayinka AKANLE Chukwu CHIOMA}

\section{Abstract}

In this article, we examined the repertoire of existences, processes and practises as well as mechanisms of open market place trading that is a definitive character of trading and associated dealings in many Sub-Saharan Africa countries which is as a result of the nature and structure of social and economic organizations cum cultural relational infrastructures of these Sub-Saharan societies. One stop shops and shopping malls that commonly punctuate American and European societies are rare necessitating special, unique and innovative ways of transporting goods and services across locations. It is within this socio-cultural, relational and economic infrastructural milieu that head porterage (Alabaru) subsists. Unfortunately, not many works exist in the areas of Anthropology and Cultural Studies on head porterage (Alabaru) which has assumed important character in the existences of most Sub-Saharan African markets with implications for global markets and world distribution/supply chains. This article therefore deployed robust Anthropological and qualitative methodology to examine the critical contours of the problematic.

Keywords: alabaru, head porterage, Nigeria, Bodija, global distribution chains

\section{Introduction}

The real and unique survival, socio-cultural and economic existences that often distinguish nations from others are often weakly attended to even at scholarship realm due to fixation at the level of popular discourses. Rather than engage in social and culturally detailed ethnographic and Anthropological study of issues relative to African realities and situations for example, contemporary social science on Africans and in Africa appears to be densely afro-positive averse (according to Olukoshi, 1998 Afro-pessimistic) thereby limiting scholarly worth of many existing literature on Africa markets especially as Africans navigate the poverty invested terrains since the 1980s. Many existing studies play to the gallery by further demonstrating ascendancy of poverty in Africa and the need to model western socio-economic spaces in Europe and America in everything Africa (cultural convergence view) rather than detailed study 166 
of also the differences and uniqueness for better and more sustainable and nuanced interrogations for understanding of the African socio-cultural and economic systems for global advantages. Examples of few of the works that have attempted such positively unique accounts of identical societies are Griffith, Garcia-Quijano, and Vald ' es Pizzini (2013) in their study of A Cultural Biography of Quality in Puerto Rican Fishing and Haynes (2013) on the social productivity of the Pentecostal prosperity gospel in Zambia. Knowledge of Sub-Saharan African markets and associated services like contemporary head porterage have been largely poorly studied due to its consideration as one of the many underdevelopment realities of Africa rather than potential Anthropologically beneficial isue. Hence, while there is some literature on pre-colonial porterage especially in relation to long distance caravans (Falola, 1984, Ogunremi, 1982, Law, 1980, and Lovejoy, 1980), little literature exist on head porterage in the context of contemporary Sub-Saharan African markets Anthropologies and cultural realities. This article therefore filled the lacunae existent in knowledge and literature on head porterage and contemporary markets in West Africa and other parts of Sub-Saharan Africa with global implications by examining the three main critical contours of pullers, social significance and contest for space in head portrage (alabaru ${ }^{1}$ ) and Sub-Saharan Africa markets. Head porterate punctuates Sub-Saharan African market/trading experience in unique ways. Most Sub-Saharan Africans, including Nigerians, buy wares and food stuffs in the open informal markets as against formalized shopping systems in America and Europe even though such shopping malls are now gradually emerging in very few Nigerian cities as new class definitions are emerging. Popular of these emerging shopping malls in Nigeria, and Accra Ghana for instance, is the Shoprite. Shoprite malls and others are only always located in high brow urban residential/business areas occupied by the rich and the middle class since the affluent and the middle class are the target markets. Hence, the shopping malls target the busy, trendy and the rich urban upper and middle classes. There are also usually many fast food restaurants in the shopping malls to service hungry shoppers to ensure beautiful total shopping experience that is relaxed and classy. Popular fast food brands that service the shoppers in the emerging urban shopping malls include; Mr. Biggs, Mama's Place, Nandos and Fatizza Sharwama².

Moreover, in Lagos, Nigeria for instance, Shoprite malls can only be seen in choice areas like Ikeja, Lekki, Ajah, Victoria Island and Ikoyi, all high 
class areas, with none in low class and rural areas. There are no Shoprite shopping malls in Mushin, Isale-Eko, Oshodi, Bariga ${ }^{3}$, Epe and Ikorodu ${ }^{4}$ . There are no Shoprite malls in Ibadan and neither are there any such big malls in the city. The only prospect and sign of near future emergence of such malls in Ibadan is the one being proposed by the Oyo state government for Ring Road Area and J-Allen Area of Ibadan. There is thus currently no such thing as ultra modern, big shopping malls in Ibadan because the city is usually considered very traditional and conservative with absence of huge upper and middle socio-economic classes with needed busy, fast and trendy lifestyles, class affinity and modern taste that could sustain such heavy investment in shopping malls.

More importantly however, even in areas where the shopping malls are located in the cities, many people still frequent traditional markets as the prudent people see products in such malls as needlessly very expensive and mere class symbols. Many African products and food stuffs particularly are also not on available in those malls. The combined effects of these two factors thus make traditional markets very patronized. In the case of Ibadan particularly, traditional open markets remain the main point of trading as at now and it is only time that will tell if this will change. This article therefore explored the following research questions (1). What are the pull factors to head porterage? (2). what is the social significance of alabaru? And (3) how are spaces contested for in the typical Sub-Saharan African market of Bodija market, Ibadan, Nigeria. This article is contextualized in the contemporary period of 1985-2012 given the critical socio-political and economic occurrences of this time in the history of Nigeria and how these occurrences could have impacted head porterage in definitive ways. Following this introduction is an examination of head Porterage in Sub-Saharan Africa. This is followed by the methodology adopted in conducting the study that led to this article and this is also followed by data presentation and discussion. The article ended with the conclusion.

\section{Head Porterage Alabaru : A Consideration of Relevant Trajectories} According to Agarwal, Attah, Apt, Grieco, Kwakye and Turner (1997), the commercial head load carrying is to be understood within the frame of economic activity and the importance of petty trading in SubSaharan Africa ${ }^{6}$. Head porters are a major part of the transport systems and structures of developing countries with poor transport and market planning ${ }^{7}$. Even if the markets have architectural master plans, this could 
be tampered with for various infrastructural and socio-political reasons. People can thus violate market master plans and outlays as they negotiate survival challenges in the urban market place. Importantly, transport responsibilities that were supposed to be performed by technology are often performed by humans in developing economies (Agarwal, Attah, Apt, Grieco, Kwakye and Turner, 1997) since it is either necessary technologies do not exist, or socio-cultural or economic or geography infrastructures do not support and negate them ${ }^{8}$.

Analytical periodization is very important for this kind of article as it is the only way issues of interest could be best situated. As already documented by Law (1980), Ogunremi (1982) and Falola (1984), head porterage predates Structural Adjustment Programme (SAP) and could even be associated with cultural expression and technologies available to the people for moving goods and transporting selves at different times. Thus, the period this article covers relative to the alabaru is 1985-2012. This is a period within which beginning and consequences of the Structural Adjustment Programme (SAP) are real and definitive. The introduction of SAP in Nigeria was in mid-1980s and the poverty and austerity measures that followed SAP began almost immediate and still being experienced in different forms today.

According to Akanle and Olutayo (2009), by the mid-1980s, Nigeria had been successfully incorporated into the contemporary global economy's elaborate and unmitigated capitalist and neo-liberal economic reforms that led to and aggravated poverty, unemployment and reversed development in the country. This incorporation was somewhat legitimated and accentuated by SAP. Negative consequences of SAP programmes co-mingled with internal/domestic government irresponsibility, corruption, nepotism, tribalism and political instability in Nigeria, like other developing nations, to exacerbate the social, political and economic problems and challenges in the country during the 1980s (Akanle and Olutayo, 2009) and even till date and it is within this socio-economic context that alabaru assume the contemporary character as against that already documented for the precolonial.

This is why it is not uncommon to associate involvement of people in poorly paid employment to Structural Adjustment Programme (SAP) and its associated developing economies, that of Sub-Saharan Africa in particular, collapse since people must survive, and as they say in Nigerian popular discourse "man must wack". (Oha, 2010, Akanle and 
Olutayo, 2009, Hashim 2007; Oberhauser and Hanson 2007, Aryeetey, Harrigan, and Nissanke, 2000). Hence, SAP reconstructed the socioeconomic structures of the Sub-Saharan African society, redefined survival mechanisms and work ethics as well as occupational belief systems as people were/are pushed to seek even unconventional and non-traditional means of livelihood in unique ways as expressed in engagement in alabaru as a trade (see also Akanle and Olutayo, 2009, Akanle, 2009, Boakye - Yiadom and Mackay, 2007, Hashim, 2007, Opare, 2003, Twumasi - Ankrah; 1995 and Krueger, Schiff, and Valdes, 1988).

\section{Research Methodology}

Qualitative method was adopted for this study. This was because qualitative method has the strength of enabling researchers to have deep and detailed view of the structural and social relations issues necessary for sufficient and valid as well as reliable data gathering for the understanding of the problematique. Both primary and secondary data were gathered for this article. Secondary data were gathered mainly through books, reliable internet documents and learned journals. Primary data were gathered through In-depth interviews (IDIs), key informant interviews (KIIs), focus group discussions (FGDs) and extended observation. 30 in-depth interviews were gathered through detailed engagements with alabaru while 4 FGD sessions were scheduled with different sets of alabaru. KIIs were also conducted with principal officers of the alabaru and market leaders. Extended non- participant observation was scheduled and undertaken in the market to capture important research issues. Since there must be relationship and synergy between methods of data collection and method of data analysis, qualitative data collected were subjected to content analysis and presented as verbatim narratives and ethnographic summaries.

As Study Area and Study Population, Bodija market in Ibadan Nigeria and practising alabaru were engaged. Ibadan is primarily both traditional and modern city with appreciable presence of hybridity. Bodija market was considered suitable for this research for at least five major reasons. First, Bodija is the most cosmopolitan market in Ibadan and among the most cosmopolitan in Nigeria. Different ethnic groups and nationalities patronise the markets both as traders and buyers. A visit to the market will reveal, clearly, the significant blend of cultural multiplicity of Nigeria as a rainbow nation as people of different ethnic nationalities and 
internationalities buy and sell in the market. Some people specialize in the sale and purchase of their traditional wares. Second, Bodija is among the most prominent and popular markets in the country and, in fact, the Africa Sub Sahara. Third, the market is among the busiest markets in Ibadan and the country. Based on our original estimation in the course of this article, the average number of people that transact business in the market per day is 15,000-20,000 people.

In addition, the usual opening period of the market is $8.00 \mathrm{AM}$ and 11.00PM. Trucks that come for off-loading of products enter the market any time of the day including midnights. For instance, it is common to see trucks offloading cattle, tubers of yam, beans and rice from the northern part of the country and hinterlands both in the day, night and midnight since their travel times are unpredictable. Many of these trucks and trailers even travel over the night for various reasons including less congested roads at night which increases their safety and accident free journeys in a nation with poor road infrastructures. Fourth, the market is among the oldest and longest existing markets in the sub-region. Lastly, the market is the most popular, in western Nigeria, for food products including cattle, tubers of yam, pepper and grains among others. This however not to suggest that only food stuffs are sold in the market as traditional, manufactured and farm produce are sold in the market.

\section{Findings and Discussion}

Contest for Space in an Urban Market: Alabaru and the organization of Bodija Market

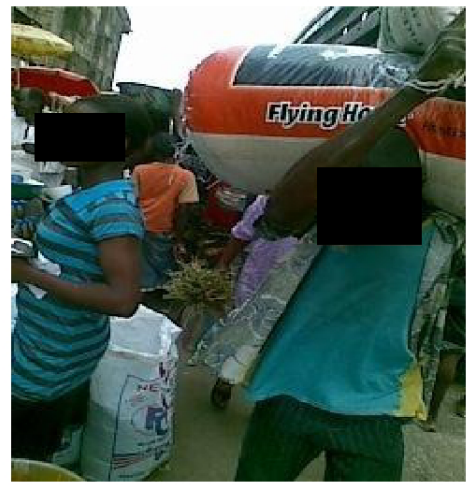

Image 1

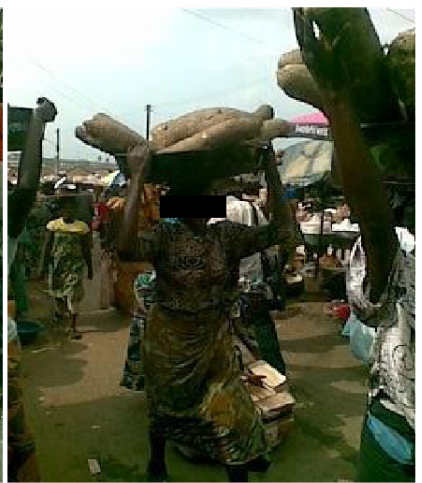

Image 2 


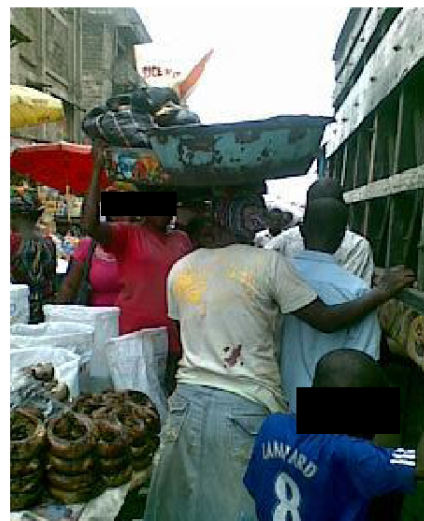

Image. 3

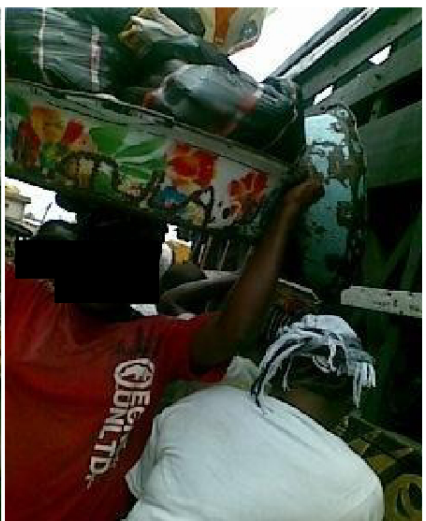

Image. 4

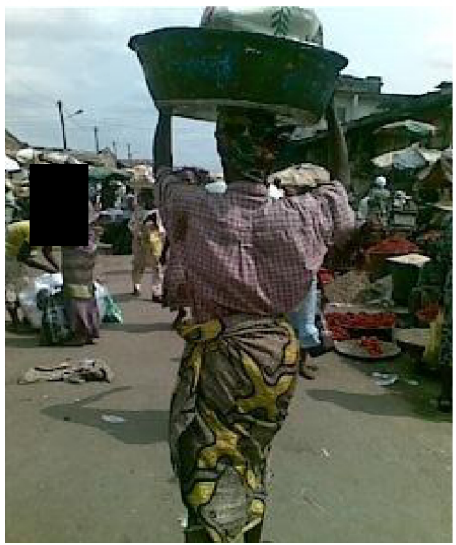

Image. 5

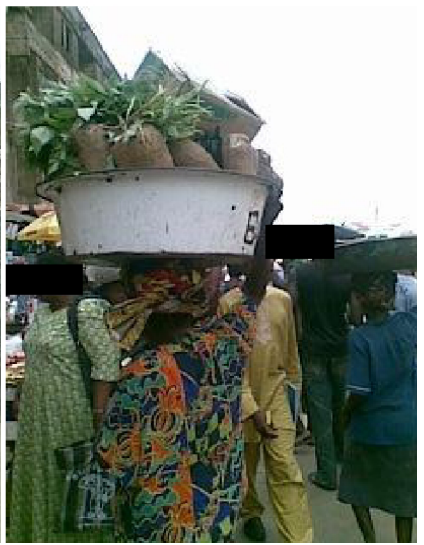

Image. 6

Images 1, 2, 3, 4, 5 and 6 show male and female porters in business. Especially many of the images show male and female head porters struggling for space and walk ways as they are transporting and carrying goods for customers. As could be seen in the images above, the organization of the market does not follow the original layout in practice. Where there are brick shops, make shift sheds are constructed very close to the walk ways of the market making movement difficult. Wares are displayed very close to the roads even by those without shops and sheds. Market women and men that could not afford the rent for shops ${ }^{9}$ and sheds are made to pay for spaces usually unplanned for and most of such spaces are the places left as walk ways. Such monies are collected by people who are usually thugs 
or layabouts who now claim to be government agents or omo onile (see also Olutayo, Akanle and Alliyu, 2012) as they are now used as political mercenaries in the democratic era (children of owners of the land).

Interestingly, many of the traders prefer such spaces along the roads as they believe such spaces are even more visible and attract customers than shops that are hidden as many customers do not have time to go deep into the market to shop but to just quickly buy their wares along the road in the market. Even many that could afford the shops still prefer to rent such spaces due to their visibility. As sellers and buyers of wares occupy the spaces, moving and transporting selves and wares become a difficult task. As could be seen in image 3, the smoked fish, the seller and the buyers are standing right at the middle of the road thereby obstructing movement. Also, truck in Images 3 and 4 was parked right at the middle of the road to offload tubers of yam for sale in the market thereby obstructing even human traffic. A closer look at images 3 and 4 show that it is impossible for two people to work side by side at the same time as people have to wait for one another to pass.

Even women alabaru carrying heavy loads on their heads had to wait for others to pass before they could continue movement. In image 4, an alabaru that has off loaded her own wares had to remove her head pan and level it with the truck since she could not wait so as to go and carry another load on time. The other alabaru with load also could not wait but continue to wriggle himself to pass on time especially as they are used to this system and the trucks would never be in a hurry to leave. It could even be there for days especially if it developed faults along the line. The best approach was therefore for the alabaru to innovate an approach to navigate the congested market even when physical obstructions like trucks are parked on the walk ways. That was the usual practice in Bodija.

Only vehicles that wanted to offload goods force their ways into the market since they must enter the market to offload. And, when they find their ways into the market, there are no functional market spaces in the market other than for them to park on the road and obstruct both human and vehicular movement. In fact, it is impossible for any shopper to enter the market with his/her vehicle as both human traffic and obstructing trucks prohibit this. If the alabaru and the other humans in the images find it extremely difficult like that to move in the market, it is then very easy to imagine how impossible it will be for shoppers to drive into the market. This is why many shoppers park along the main road sometimes far from 
the market (illegal parking though) and patronize alabaru to transport their goods to the car after shopping.

\section{Pullers (Pull factors) of alabaru}

Like all careers and professions as well as occupations, there are factors that must either pull people to or push people away. Also, given the nature of alabaru it is important to examine and document the pull factors to have a robust view of the subject matter. Thus, this was captured in this article. Pull factors of alabaru were myriad but could be captured as mainly: poverty and unemployment after a long time of unsuccessful search for the originally desired job most of the alabaru therefore only took the job as a last option since they must be kept busy and productively get engaged to survive in an already poverty invested society. A person interviewed during IDI in the course of the researched vividly captured the subject of pull factors of alabaru as follows ${ }^{10}$ :

Why I engaged in this business is because of hunger and poverty, my husband has no work and we need money to take care of the family.' When there is no money, no helper and one has the responsibility of taking care of the children and to send them to school. The relevance of the job is that one can start it without capital and it is a form of self employed job in which you are not being controlled by anybody ${ }^{11}$.

(IDI/Female/Ibadan/2011)

We interviewed another alabaru this was what she said:

Because of unemployment and poverty. When the government did not provide jobs, many people are unemployed and rather than staying at home, women got engaged in this job. I got engaged in this business because I have to care for my children in school. What actually led to the emergence of the trade was because of lack of employment and poverty. We have no helper, that is why we got engaged in this business. And some people have become debtors, so through this job they are able to pay up their debts. The relevance of the job is that it does not require any capital to start with.

(IDI/Female/Ibadan/2011)

The above summaries were not limited to the women alabaru only. The male ones interviewed shared the same orientation. According to a man we interviewed:

I got engaged in this business because of the economy of the country, because there is no money and helpers. What we generate as income 
(as alabaru) is not enough but it can still cater for something.

(IDI/Male/Ibadan/2011)

We discovered a strong relationship and agreement between data we gathered from IDIs and FGDs. A discussant gave a very insightful and nuanced view that was well agreed with by other discussants:

When the government did not provide jobs, many people are unemployed and we have to look for another means of survival. It is not a work that is learnt, but because of unemployment we have to do it to get some money and invest in a more lucrative job. Some of us are graduate amongst us, but because of unemployment we got engaged in this job. We have a association and we also belong to an association because of the safety of the job which involves offloading of goods and because of organization. We have good foundation association and ojuenimala (somebody that will be prosperous) that will association which is divided Into two and at least with fifty members. The association was formed in order to help one another.

(FGD/male/Ibadan/2011)

These ethnographic summaries above demonstrated the recruitment and disengagement process of the alabaru job. They also vividly gave the reasons for the alabaru engagements in the first instance. It is important to note that engagement in the job becomes very understandable against the background of the period being covered in this article (1985-2012). This has been an economically difficult period in the contemporary history of Nigeria. Unemployment is rife and poverty in Nigeria is a major problem. Unemployment and poverty thresholds in Nigeria are 15 and 70-90 percent respectively. Absolute poverty in Nigeria is 70 percent measured on the percentage of Nigerians that live on $<\$ 1$ per day and 90 percent of Nigerians measured on the percentage of Nigerians that live on measured $<\$ 2$ per day.

Unfortunately, the rate of poverty is estimated to increase in the country except there is deliberate intervention that creates alternative sources of revenue in the country (Sanusi, 2012). Right now, Nigeria only depends on foreign exchange from crude oil export and even the foreign exchange earnings from oil has not been judiciously used due to excessive corruption and poor governance in the country. The ensuing aggravated poverty has thus somewhat weakened the conception and practice of African kinship and family as the social support systems of Africans (see Akanle 
and Olutayo, 2011). The social relations and cultural infrastructures that usually support Africans in the absence of state welfare support system as existent in the American and European societies have been weakened as the Sub-Saharan African society becomes survival of the fittest in the face of high rate of poverty.

Usually, alabaru join the trade as a temporary survival measure and to source capital to be reinvested in other careers that are less tedious and more prestigious. The alabaru job thus serves a twin purpose of meeting immediate needs and the more sustainable needs of future reinvestment in originally intended more prestigious and less difficult jobs. Most of the alabaru have original skills they have trained in but may have to join alabaru to raise initial capital which they could not raise from any other source as already mention by some in the ethnographic summaries above, because they lack helpers. It is important to note however that while many have exit strategy of raising capital and leaving, many end up been stranded in the job. Many enter find it difficult to fulfill their desire of raising capital and continue longer time than they had anticipated originally. The reasons why many get stranded in the job are complacency and lifestyles. Many lack the capacity to save as their propensity to consume heavily outweighed their propensity to save. Many also get used to daily pay (wages) alabaru brings and continue in the circle rather than saving and exiting into their original intended which may not bring daily pay but instead salary or irregular sales.

Also the alabaru job may appear unstructured to an outsider and uninitiated, it is structured as no one is allowed to just enter the market and start the job. Associations are organized around the business especially among the males. He primary function of the association are; to regulate entry, to fraternize in order to protect members from been violated by customers and market officials and to educate members. While women mostly carry loads on their heads, a lot of males push wheel barrow to transport heavy goods. This is however not to suggest that males do not carry leads on their heads. Some carry on their heads, push wheel barrows and carry goods on their shoulders. Female alabaru however seldom push wheel barrow as they only carry loads they have the strength to carry on their heads.

An established alabaru captured the situation as follows:

We started the trade by making use of trays or basins for conveying the goods while the men carries the goods on their shoulders or most times use trucks. Trucks are mostly used by men because it requires strength 
to push it and as a woman since we do not have much strength to push trucks we rather make use of trays or basin. We do not have an association because we have not called ourselves together to form an association. It is only the male that has association because one cannot just come to the market with a wheel barrow, without being questioned.

\section{(IDI/Female/Ibadan/2011)}

It is however noteworthy that that not all alabaru were uneducated. Some were very educated and took to alabaru because they could neither get desired paid jobs nor afford further studies. They therefore joined alabaru to either raise fund for further studies or to meet immediate survival needs like feeding, shelter and clothing. It is then appropriate to maintain that the educated only took to alabaru as a short term survival strategy to exit immediately they get desired white collar jobs or save enough money for further studies. This finding therefore falsify the earlier research findings on the subject for instance in Ghana where head porters are only seen as people who were migrants, unskilled and poorly educated (Hashim, 2007, Opare 2003 and kwankye, Anarfi, Tagoe and Castaldo, 2009).

\section{Social Significance of Head Porterage}

Largely, head porterage is not seen as an enviable or prestigious job. In fact, people look down on the alabaru as frustrated and hopeless people. They are seen as people with no education and are skills deficient. Due to this, they are addressed without much deserved respect in most instances. The name alabaru is symbolically synonymous with representation of subservient relationships between the alabaru and the shopper. It can be literally seen as this very heavy load and dirty wares I cannot carry, you come and carry it for me for a token (insignificant amount) since you are helpless and I am better than you. And, this orientation and attitude inform the social relations that subsists among the alabaru, the shoppers and the significant others in the society. While the alabaru render very crucial and critically important service as transportation chain complement in very chaotic African urban markets and veritable employment in acute employment shortage systems of Africa, this critical socio-economic values are poorly appreciated by the people and even the governments. The alabaru are largely able to meet their immediate needs and get busy through the job as they charge money for their services. Charges usually depend on weight of the goods to be carried (how heavy is the $\operatorname{load}^{12}$ ) and distance ${ }^{13}$ to be covered while carrying the load (the farther the more 
expensive).

Hence, the only sometimes exceptional case where alabaru may be accorded a little respect and fair treatment is relative to age. That is, if the alabaru is more elderly and older than the shopper or any other person in the trade and market relationship. This is important and sometimes alluded to in treatment given the strong African traditional gerontocratic social structure. Even in such instance, depending on the level of development of relationship etiquette and courtesy of the individual shopper that transcends the immediate alabaru relationships, even the older alabaru may still be maltreated and related to with disrespect as an insignificant other. This is commonly so as many shoppers, youths and the adults, have imbibed elaborate modernization and their sense traditional values that are important for gerontocratic observance in relationships have been largely eroded or being driven to the background. Against this background the following accounts for data gathered from the field are insightful.

According to a discussant:

When you come, most of the time there is market (patronage), but sometimes not. When there is no market (patronage) you cannot make money. We make money and charge depending on the distance, from \#30 to\# $40^{14}$. Though what we generate daily is never enough, at least it can sti 11 cater for something. I can generate up to 400 (\$2.5 USD) to $\# 500$ ( $\$ 3.5$ USD) minimum a day. The job is tedious and you have to work hard to earn enough money. I am not happy doing the job because it is suffering. People see us poor and suffering people. The relevance of the job is that when shopper comes to shop we assist them in carrying their goods to their destination and get paid for the service.

\section{(IDI/Female/Ibadan/2011)}

A female IDI interviewee pointed out:

The job provides one the opportunity of being self employed, though It is not an easy work. It is a kind of job that anyone that comes into the business is sure to take money home because it does not require any capital to start with. We do not belong to an association and we do not have an association, anybody can come and join in the business. As a result of our educational qualification, the job still create opportunity for us to earn a living. Though what we generate as income is not enough, but it can still cater for something.

(IDI/Male/Ibadan/2011) 
Though there is no prestige in doing the job, people look down on us as poor and suffering people but at least we are still able to make some money and cater for ourselves.

(IDI/Female/Ibadan/2011)

There is no happiness in doing the job because there is a lot of sufferings associated with it, we are being embarrassed. People look down on us as poverty ridden people and sometimes call us thief's that we should not go away with their goods.

(IDI/Male/Ibadan/2011)

Sometimes there is familiarization. A person develops trust and asks you to carry more often. But at the other hand sometimes you are accused of stealing or things like that. A lot of embarrassment are associated with the job. Most of the time the clients talk to us anyhow. In terms of prestige of work they see us with the eyes of poor and suffering people.

(FGD/Female/Ibadan/2011)

Against this backdrop, it could be observed that the alabaru are only negatively concerned due to the uncomplimentary and the socially demeaning treatments they regularly receive from customers at the market, other people and even kin who see alabaru job as socially insignificant in society. This is because the society has huge attraction to white collar jobs like banking and working in telecommunication companies. The alabaru studied maintained the fact that the job is good enough to cater for their needs. The only regret they have is based on the uncomplimentary treatments people give them because of the job.

\section{Conclusion}

This articled has examined three critical forces of head porterage in an urban market of Bodija Ibadan, Oyo state, Nigeria. Issues examined were; contest for space, pull factors and social significance. These are important factors moderating the practice of alabaru and determine the outcomes of the job on the practitioners and society at large. The primary focus of the article has been the need to demonstrate the realities of this job as a unique practice that must be better explored for the purposes it serves in order to better understand the socio-economic and cultural processes, currents and infrastructures of Africa, especially the Sub-Sahara. It is therefore important that head porterage be better focussed in contemporary terms, and not abandoned to pre-colonial African studies; perhaps some 
of its trajectories could be better appreciated and understood as greater knowledge pathways of Africa to drive knowledge and development. Head porterage in Sub Saharan Africa thus remains a unique and definitive character of Nigerian and West African Urban market as ever even as the Nigeria and the sub-region confront and battle parochial knowledge and development challenges in 21 st century and beyond.

\section{Endnotes}

${ }^{1}$ Alabaru among the Yoruba are also known as carry carry in the Niger Delta region, Kayayei in Ghana and kaya among the Hausas (see Ikporukpo, 2005; Adamu, Filani and Mamman, 2005; Ahmed and Rikko, 2005; Adepetu, Olaniyan and Daloeng, 2005; Adebayo, Ezedinma, Okechukwu and Sanni, 2005 and Adejobi and Ayinde, 2005, Agarwal, Attah, Apt, Grieco, Kwakye and Turner, 1997; Apt and Gierco 1997; Opare 2003; kwankye, Anarfi, Tagoe and Castaldo, 2009, Korboe 1996; Beauchemin, 1999).

${ }^{2}$ See Olutayo and Akanle (2009a) for a detailed discussion on fast food in Nigeria.

${ }^{3}$ These are urban poor areas

${ }^{4}$ Epe and Ikorodu are rural areas usually considered poor zones

${ }^{5} \mathrm{Head}$ porter (alabaru) is one that carries goods or burdens for someone else, charging for the service. Literally, alabaru is a Yoruba word for anyone that carries goods or luggage on the head for another person for a fee. In contemporary time however, alabaru now adopt many methods of moving goods and these other methods aside the head include shoulders and wheel barrows.

${ }^{6}$ Emphasis added by the authors

${ }^{7}$ Please see Awumbila, 2007, Kwankye, Anarfi, Tagoe and Castaldo, 2007, Rockel, 2000, White, 2000, Aggarwal, 2000 and Netting, 1993 for more information on the different names used to describe alabaru across the Sub-Saharan Africa and trajectories of involvement in the trade.

${ }^{8}$ See also Law (1980) for interesting accounts on elements and determinants of technology adoption, particularly Wheeled Transport, in transportation of goods as interface of head porterage in African pre-colonial history. See also Ogunremi (1982). Counting the camels: the economics of transportation in pre-industrial Nigeria. New York: NOK Publishers International and Falola (1984) The Political Economy of a Pre-colonial African State Ibadan, 1830-1900 for other useful information on the general political economy of precolonial Africa and particularly on pre-colonial porterage relative to long distance caravans. ${ }^{9}$ Lock up shops are usually very expensive and very unaffordable for most people in viable urban markets like Bodija thereby making many either hawk their wares on the head or display wares by the road.

${ }^{10}$ It is impossible to cite all the ethnographic summaries from the massive qualitative data 
gathered from the field in this article. Therefore, only the summaries that most represented the pattern of findings and group consensus (in the case of FGDs) were presented in this article.

${ }^{11}$ It is important to say that this summary represent the modal response from the interviews. That is, most of the other alabaru interviewed shared this view.

${ }^{12}$ This is done through mental estimation of the weight as they see the load on the ground. This also depends on the alabarus' experience in the trade. That is if he/she has carried such loads before in the past and the cultural familiarity with the products/goods to be carried. ${ }^{13}$ No technical equipment is used for this. It is based on the mental map of the alabarus as they are familiar with the geography of the market. This is also based on the alabarus experience, expertise and the familiarity with the market.

${ }^{14}$ This is far less than a dollar. This is like a quarter of a dollar. A dollar is about \#160 Naira (Naira is Nigerian currency)

${ }^{15}$ Between the alabaru and particular clients which makes the shopper prefers particular alabaru as regular customer to always use when he/she comes for shopping at the market. This is sometimes based on trust the shopper has developed in the alabaru in terms of wares security during transportation. This is important as alabaru are sometimes suspected of stealing shoppers' goods as they have the capacity to move more briskly and navigate the chaotic market easily, based on experience and expertise, which an average shopper may not be able to do. Most times, the shoppers may lose sight of the alabarus who may have gone far ahead of the shoppers. This is usually an opportunity for the criminally minded ones to abscond with the wares and goods leaving the shoppers stranded.

\section{References}

Adamu, F, Filani, M and Mamman, A.B. (2005). Market and transport institutions in Nigeria's livestock trade: Case studies from Sokoto and Ibadan. Investigations on Building a Food Marketing Policy Evidence Base in Nigeria CNTR 04 5785 Briefing Report, November. Gina Porter, University of Durham, UK, Fergus Lyon, University of Middlesex, UK and The Nigerian Marketing Network Pp. 35-58.

Adebayo, K. (2005). Traditional institutions and information uptake in the conduct of cassava fufu market. Investigations on Building a Food Marketing Policy Evidence Base in Nigeria CNTR 045785 Briefing Report, November. Gina Porter, University of Durham, UK, Fergus Lyon, University of Middlesex, UK and The Nigerian Marketing Network Pp. 102-120. 
Adejobi, A.O. and Ayinde, I.A (2005). Market institutions for cowpea in Maiduguri and Abeokuta. Investigations on Building a Food Marketing Policy Evidence Base in Nigeria CNTR 045785 Briefing Report, November. Gina Porter, University of Durham, UK, Fergus Lyon, University of Middlesex, UK and The Nigerian Marketing Network Pp. 142-163.

Adepetu, A.A. Olaniyan, J.A.O. and Daloeng, H.O. (2005). Institutions and interactions in vegetable marketing in Jos: The case of Farin Gada tomato market. Investigations on Building a Food Marketing Policy Evidence Base in Nigeria CNTR 045785 Briefing Report, November. Gina Porter, University of Durham, UK, Fergus Lyon, University of Middlesex, UK and The Nigerian Marketing Network Pp. 81-101.

Agarwal, S., Attah, A., Apt, N., Grieco, M., Kwakye, E.A., and Turner, J. (1997). Bearing the weight: The Kayayoo-Ghana's working girl child. Centre for Social Policy Studies, Faculty of Social Studies, Accra: University of Ghana.

Aggarwal, R. 2000. Point of departure: Feminist locations and the politics of travel in India. Feminist Studies. 26 (3), Pp. 535-562.

Ahmed, B. and Rikko, L. (2005). Market institutions for maize in Northern

Nigeria. Investigations on Building a Food Marketing

Policy Evidence Base in Nigeria CNTR 045785 Briefing Report, November. Gina Porter, University of Durham, UK, Fergus Lyon, University of Middlesex, UK and The Nigerian Marketing Network Pp. 59-80.

Akanle O. (2009). Immigration cultism and the Nigerian migrants: Tidal dynamism in the age of globalization. In Adebayo, A.G. and Adesina, O.C. (eds). Globalisation and Transnational Migrations: African and Africa in the contemporary Global System. UK: Cambridge Scholars Publishing. Pp. 181- 200.

Akanle, O. and Olutayo, A.O. (2009). Emancipating remittance discourse: A look at extra-financial remittance in Nigeria. Global Development Studies: International Development Options. 5. 3-4. Pp. 189-212.

Akanle, O. and Olutayo, A.O. (2011). Kinship construction variability 
among Nigerian international migrants: The context of contemporary diaspora. Human Affairs. 21. 4. Pp. 470480 .

Apt, N.A. and Grieco, M. (1997). Listening to girls on the street tell their own story: What will help them most? Centre for social policy Studies, Faculty of Social Studies, Accra: University of Ghana, Legon.

Aryeetey, E., Harrigan, J., and Nissanke, M. (eds.) (2000). Economic reforms in Ghana: The miracle and the mirage. Accra: Woeli Publishing Services.

Awumbila, .M. (2007). Internal migration, vulnerability and female porters in Accra, Ghana. Retrieved From http://paa2007. princeton.edu/download.aspx?submissionId=70865

Beauchemin, E. (1999). The Exodus - the growing migration of children from Ghana's rural areas to the urban centres. Catholic Action for Street Children and United Nations International and Children's Educational Fund. Boakye-Yiadom, L. and MacKay, A. (2007). Migration between Ghana's rural and urban areas: The impact of migrant's welfare. Presented at PEGnet Conference, Berlin, Germany. September 2007.

Ezedinma, C, Okechukwu, R. and Sanni, L. (2005). Marketing of gari in Benin City and Enugu, Nigeria. Investigations on Building a food marketing policy evidence base in Nigeria CNTR 045785 Briefing Report, November. Gina Porter, University of Durham, UK, Fergus Lyon, University of Middlesex, UK and The Nigerian Marketing Network Pp. 121-141.

Falola, T. (1984). The political economy of a pre-colonial african state Ibadan, 1830-1900. Ife: University of Ife Press. Guyer, J.I. (1980). Female farming and the evolution of food production patterns amongst the Beti of south-central Cameroon. Africa: Journal of the International African Institute 50. 4. Pp. 341-356.

Hashim, I. (2007). Independent child migration and education in Ghana.

Development and Change. 38. 5. Pp. 911-931.

Ikporukpo, C.O. (2005). Ethnicity and social networks in a fish marketing system, Warri, Nigeria. Investigations on Building a 
Food Marketing Policy Evidence Base in Nigeria CNTR 045785 Briefing Report, November. Gina Porter, University of Durham, UK, Fergus Lyon, University of Middlesex, UK and The Nigerian Marketing Network Pp. 19-34

Kalala, K .P. (1999). Assessment report on women and poverty and the economic empowerment of women. Proceedings of the 6th African regional economic commission conference on women. 22 - 26th November 1999. Ethiopia Addis Ababa.

Korboe, D. (1996). A profile of street children in Kumasi. Report Commissioned by UNICEF and RESPONSE. Street Child Study, Part Two.

Krueger, A. Schiff, M. and Valdes, A. (1988). Agricultural innovations in developing countries: ? Measuring the effects of sectoral economy-wide policies, The World Bank Economic Review. 22. 3. Pp. 255-271

Kwankye, S.O., Anarfi, J.K., Tagoe, C.A. and Castaldo, A. (2007). Coping strategies of independent child migrants from northern Ghana to southern cities. Development Research Centre on Migration, Globalisation and Poverty, University of Sussex, Working Paper T-23.

Law, R. (1980). Wheeled transport in pre-colonial West Africa. Africa: Journal of the International African Institute. 50. Pp. 249262.

Lovejoy, P. (1980). Caravans of kola, the Hausa kola trade 1700-1900. Zaria: Ahmadu Bello University Press/University Press Ltd.

Netting, R. (1993). Smallholder, householders farm families and the ecology of intensive sustainable agriculture. Stanford, CA: Stanford University Press

Oberhauser, A.M. and Hanson, K.T. 2007. Negotiating livelihoods and scale in the context of neoliberal globalization: Perspectives from Accra, Ghana. African Geographical Review 26: Pp. 11-36.

Ogunremi, G.O. (1982). Counting the camels: the economics of transportation in pre-industrial Nigeria. New York: NOK Publishers International 
Oha, .O. (Nov. 02, 2010). The alabaru of many load. Shibboleth. Retrieved June 29,2011 from http//www.tribunngrworld. com \nov 0210- shibboleth- 2579765.htm.

Olukoshi, A. (1998). Facing the challenges of African renewal. In CASS, The Challenge of African Development: Tributes and essays in honour of Claude Ake. Port Harcourt: CASS, Pp. 91-119.

Olutayo and Akanle, 2011. Olutayo A.O and Akanle O. 2009. Fighting the poverty war: Non-Governmental Organisations and the challenge of poverty eradication in Nigeria in Mutis, A.P. and Okuro, S.O. (eds.) Strategies against Poverty: Designs from the North and Alternatives from the South. Argentina: CLACSO-CROP, OSSREA and SEPHIS. Pp. 245-272.

Olutayo, A.O and Akanle O. (2009a). Fast food in lbadan metropolis: An interrogation of an emerging consumption Pattern. Africa. 79.2. A journal being published by the Edinburgh University. U.K. Pp. 207227.

Olutayo, A.O and Akanle O. (2009b). Aso-Oke (Yoruba's hand woven textiles) usage among the youths in Lagos, Southwestern Nigeria. International Journal of Sociology and Anthropology. 1.3. Pp. 062-069

Olutayo, A.O. Akanle, O. and Alliyu, N. (2012). Ethnography of development planning in southwestern Nigeria: The case of Ogere. The Nigerian Journal of Sociology and Anthropology. (Forthcoming).

Opare, J.A (2003). Head porters in southern Ghana. Journal of Social Development in Africa. 18.2. Pp. 33-48.

Rockel, S.J. (2000). Enterprising partners: Caravan women in nineteenth century Tanzania. Canadian Journal of African Studies. 34. 3. Pp. 748-778.

Sanusi, L.S. (2012). Sanusi predicts increase in Nigeria's poverty level. Accessed from http://www.vanguardngr.com/2012/02/ sanusi-predicts-increase-in-nigerias-poverty-level/ on 23rd June, 2012 at 9:05 AM GMT.

Takyiwaa, M. (1987).Ghana: Women in the public and informal sectors under the economic recovery programme. In: Nalini 
Visvanathan, Lynn Duggan, Laurie Nisonoff and Nan

Wiegersma (eds.), The Women, Gender and Development Reader, pp. 277-284. London: Zed Books Ltd.

Twumasi-Ankrah, K. (1995). Rural-urban mMigration and socio-economic development in Ghana: Some discussions. Journal of Social Development in Africa. 10. 2. Pp. 13-22.

White, E.F. (1981). Creole women traders in the nineteenth century. The International Journal of African Historical Studies, 14, No. 4, Pp. 626-642. 